I N T ER N ATIONAL MONETARY FUND

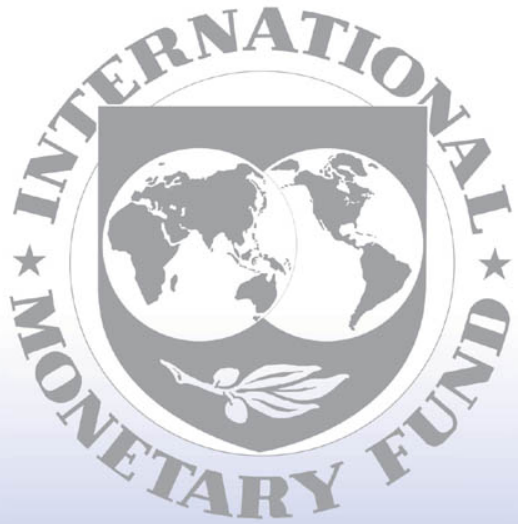

Staff

Country

Reports 


\title{
Mali: Ex Post Assessment of Longer-Term Program Engagement-Staff Report; Statement by the Executive Director for Mali; and Public Information Notice on the Executive Board Discussion
}

In the context of the ex post assessment of longer-term program engagement, the following documents have been released and are included in this package:

- $\quad$ Staff Report of the Ex Post Assessment of Longer-Term Program Engagement, prepared by a staff team of the IMF, following discussions that ended on March 18, 2011, with the officials of Mali on economic developments and policies. Based on information available at the time of these discussions, the staff report was completed on May 26, 2011. The views expressed in the staff report are those of the staff team and do not necessarily reflect the views of the Executive Board of the IMF.

- $\quad$ Statement by the Executive Director for Mali

- $\quad$ Public Information Notice, summarizing the views of the Executive Board as expressed during its June 13, 2011 discussion of the staff report

The policy of publication of staff reports and other documents allows for the deletion of market-sensitive information.

\author{
Copies of this report are available to the public from \\ International Monetary Fund $\bullet$ Publication Services \\ $70019^{\text {th }}$ Street, N.W. $\bullet$ Washington, D.C. 20431 \\ Telephone: (202) 623-7430 • Telefax: (202) 623-7201 \\ E-mail: publications@imf.org Internet: http://www.imf.org
}

\section{International Monetary Fund \\ Washington, D.C.}




\section{MALI \\ Ex Post Assessment of Longer-Term Program Engagement}

Prepared by a Staff team from SPR, AFR and INS ${ }^{1}$

Approved by the African and Strategy, Policy and Review Departments

May 26, 2011

Contents

Page

Key Issues $\underline{3}$

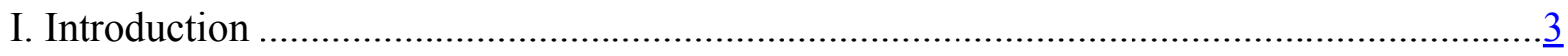

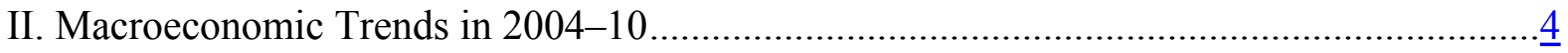

III. Assessment of Fund Involvement..................................................................................

A. Fund-Supported Programs: Objectives and Policies....................................................... $\frac{6}{6}$

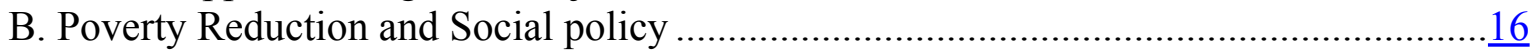

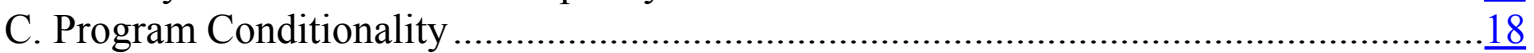

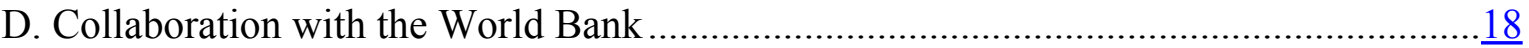

E. Concluding Remarks on the Effectiveness of the Programs.........................................

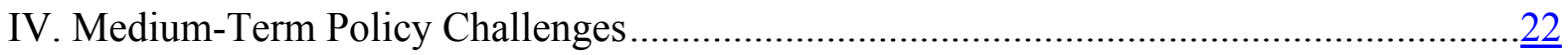

Tables

1: Quantitative Program Objectives and Outcomes, 2004-10 ...........................................

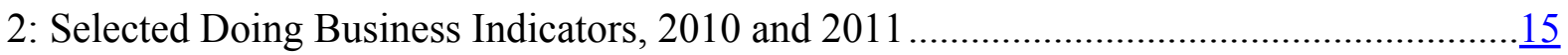

3. Quantitative Performance Criteria and Financial Performance Indicators Under PRGF

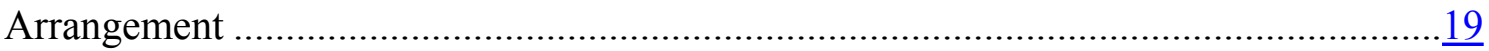

4: Structural Conditionality Under the PRGF-Supported Programs.......................................

Figures

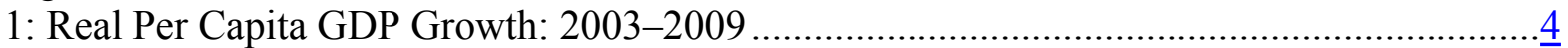

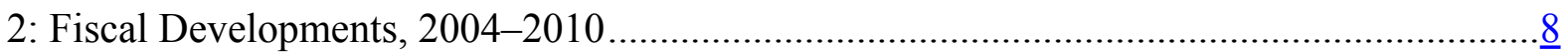

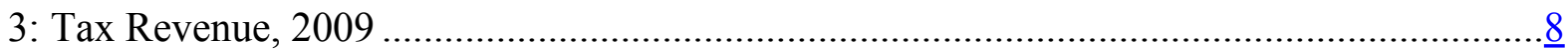

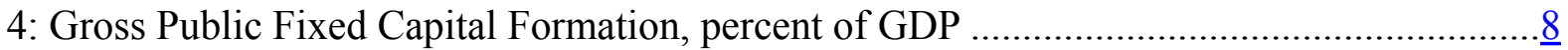

\footnotetext{
${ }^{1}$ The team comprised Richard Harmsen (head, SPR), Katrin Elborgh-Woytek (SPR), Mitra Farahbaksh (AFR) and Eric Verreydt (INS). The team had discussions with the authorities, World Bank staff, and Fund staff assigned to Mali during the period under review.
} 
5: Gross Private Fixed Capital Formation, percent of GDP $\underline{15}$

6: Selected Millenium Development Goals, 1990-2015

Boxes

1. Financial Sector Development $\underline{11}$

2. Reform of the Cotton Sector

Annexes

I. Selected Economic and Financial Indicators, 2008-14 .$\underline{26}$

II. Comments of the Government of Mali on the Report Assessing Mali's Cooperation Programs (2004-2011) with the IMF .$\underline{27}$ 


\section{Key Issues}

- Macroeconomic performance in Mali remains vulnerable to swings in agricultural production and commodity prices, and the country faces daunting development challenges, including creation of employment for a rapidly rising labor population.

- The authorities have managed to maintain a relatively stable macroeconomic environment under the Fund-supported programs. However, growth has remained below the average for sub-Saharan Africa.

- Mali will need to redouble its efforts to implement structural reforms, diversify its economy, and create conditions for higher private sector investment.

- A new Fund program would be helpful going forward, given Mali's large external financing requirements and the importance of structural measures.

\section{INTRODUCTION}

\section{This Ex Post Assessment (EPA) reviews Mali's objectives and performance} under Fund-supported programs from 2004 to 2011. Two periods of Fund involvement are assessed: the Poverty Reduction and Growth Facility (PRGF) arrangement approved in June 2004, of which the $6^{\text {th }}$ and final review was completed in October 2007; and the PRGF/Extended Credit Facility (ECF) arrangement approved in May 2008, which was extended through December 2011. This EPA is submitted for consideration by the Executive Board prior to a possible request for a new ECF arrangement following the expiration of the current arrangement. ${ }^{2}$ The authorities' response to the EPA is attached to this document (Annex 2).

\section{2. $\quad$ Earlier Fund-supported programs were reviewed in Mali's first EPA, which was} discussed by the Executive Board in December 2003. ${ }^{3}$ Directors agreed at the time that Mali had made important progress with respect to macroeconomic management and implementation of structural reforms, but that key challenges remained to be addressed, including consolidating the fiscal position, bolstering competitiveness and diversifying the

\footnotetext{
${ }^{2}$ In accordance with the revised policy on EPAs, an EPA report (instead of an update of the 2003 EPA) has been prepared as Mali has had a program interruption of more than 6 months during the period under review. See Ex Post Assessments of Members with a Longer-Term Program Engagement - Revised Guidance Note $(\mathrm{SM} / 10 / 45)$.
}

${ }^{3}$ http://www.imf.org/external/pubs/cat/longres.cfm?sk=17123.0 
economy, and enhancing the business climate - including through privatization and improved governance - in order to spur growth and reduce poverty.

\section{Mali ranks among the world's poorest countries, with a per capita GDP of about} US\$740 in 2010, and confronts serious developmental constraints. The country is landlocked with a predominantly poor and highly dispersed population. It is located in the heart of the Sahel, a region threatened by drought and desertification. It is the largest among the Economic Community of West African States (ECOWAS) countries by land area. Most of the population lives in rural areas, where poverty and reliance on rain-fed subsistence agriculture are widespread.

4. This EPA report is organized as follows. Following a brief presentation of macroeconomic trends in 2004-10 (Section II), the report discusses the authorities' main objectives under the programs, the way these objectives were translated into specific policy measures, and the effectiveness of the programs (Section III). The report concludes with a discussion of medium-term policy challenges and priorities for a possible future program (Section IV).

\section{MaCroeconomic Trends IN 2004-10}

\section{Macroeconomic performance in Mali remains vulnerable to swings in} agricultural production and commodity prices. With about 33 percent of GDP generated by agriculture (mainly food crops, cotton lint and livestock), economic activity is highly dependent on natural events and trends in crop yields. During the period 2004-10, the average GDP growth rate was about $4 \frac{1}{2}$ percent per annum ( 2.2 percent on a per capita basis), somewhat higher than in other West Africa Economic Monetary Union (WAEMU) countries but well below the average for sub-Saharan Africa, reflecting weak growth in the secondary and tertiary sectors, and bad harvests in 2004 and 2007 (Annex 1, Figure 1).

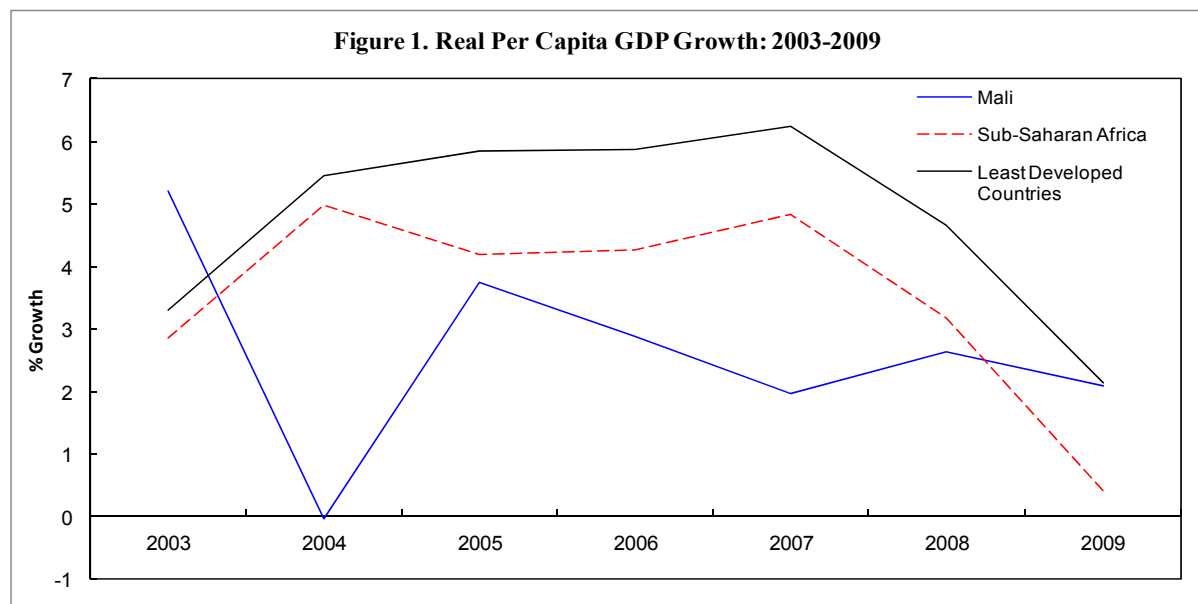

Source: WEO database 
6. Mali's relatively weak growth performance can be attributed to several factors. As discussed in the October 2010 Regional Economic Outlook (REO) for sub-Saharan Africa, ${ }^{4}$ growth in the countries of the WAEMU has been significantly lower than in high-growth non-oil exporters in sub-Saharan Africa. Relatively low foreign and domestic investment, in combination with weak non-price competitiveness, are among the key factors explaining the growth gap in the WAEMU countries, including Mali.

7. The terms of trade during the period 2004-2010 improved markedly, reflecting the sharp rise in gold prices during this period. While agricultural production remained key for the economy in terms of income generation and employment, gold exports dominated merchandise exports, constituting more than two-thirds of total exports. Notwithstanding the rising value of gold exports, current account deficits (excluding grants) exceeded 10 percent of GDP in most years, underlining Mali's high dependence on foreign aid and debt relief. The real effective exchange rate continued to appreciate during the period, pointing to some overvaluation in $2010 .^{5}$

8. The impact of the global financial crisis in $\mathbf{2 0 0 9}$ has been limited. Reflecting the low degree of integration of Mali's economy in global trade and finance, domestic economic activity was relatively sheltered from the sharp fluctuations in international trade flows and financial markets that affected so many other developing countries. Thanks to a good harvest and rising gold prices, economic activity remained sustained during the crisis period.

9. Mali's membership of the CFA franc zone has helped the authorities to maintain low and stable rates of inflation. Inflation expectations are well under control, with consumer price inflation averaging about 3 percent per year during 2004-10. Headline inflation rose during the food and fuel crisis in 2008, but less than in many other countries in sub-Saharan Africa, as second round inflation effects remained weak.

\section{The overall fiscal policy stance was broadly satisfactory during the period}

2004-10. Budget deficits have been on a sustainable path, even though they tend to exceed somewhat the WAEMU convergence criterion for the basic budget balance ( 0 percent of GDP or above). ${ }^{6}$ The execution of the budget and revenue performance, however, has been characterized by weaknesses, including recurrent accumulation of domestic payment arrears.

\section{The latest debt sustainability analysis (conducted on the basis of end-2009 data)} shifted Mali's classification from low to moderate risk of debt distress. This revision was a reflection of increased vulnerabilities from volatile gold exports and uncertain prospects for

\footnotetext{
${ }^{4}$ http://www.imf.org/external/pubs/ft/reo/2010/AFR/eng/sreo1010.htm

${ }^{5}$ See the staff report for the 2010 Article IV consultation (http://www.imf.org/external/pubs/ft/scr/2010/cr10255.pfd).

${ }^{6}$ Domestic revenue (i.e., excluding grants) less domestically financed expenditure.
} 
export diversification. Mali reached the Heavily Indebted Poor Countries Initiative (HIPC) completion point in 2003, and received debt relief under the Multilateral Debt Relief Initiative (MDRI) in 2006.

\section{ASSESSMent OF Fund InVolvement}

\section{A. Fund-Supported Programs: Objectives and Policies}

\section{Both programs under review put macroeconomic and financial stability and} strong, sustainable growth at the center of government policy objectives. The programs emphasized economic growth to follow up on the conclusions of the 2003 EPA that Mali's long-term growth performance had not been sufficient.

\section{Exogenous risks to the programs, mainly emanating from Mali's dependence on} commodity exports, were correctly identified. Overall, exogenous shocks had a mixed effect on economic conditions: the unfavorable effects of the weather-related drop in agricultural production in 2004, the food and fuel crisis in 2008, and the global financial crisis in 2009 , were to a large extent offset by the unexpectedly sharp rise in gold export prices during the period.

\section{Program design, conditionality, and Fund technical assistance appropriately} supported the program objectives. Quantitative program objectives were aimed at safeguarding fiscal sustainability and creating the fiscal space needed to increase development spending, including on health, education and the infrastructure (Table 1). The programs aimed to achieve this through a balanced mix of tax measures and more effective expenditures. At the beginning of the first program, the government's revenue strategy aimed at reforming tax policy and tax administration, and boosting tax revenue to 17 percent of GDP over time, in line with the WAEMU convergence criterion. Expenditure policy was designed to contain the wage bill, while meeting the Poverty Reduction Strategy Paper (PRSP) objectives, especially in the areas of education, health, and infrastructure, and improving the public expenditure management system. Mali has received from the Fund (including through West Africa Regional Technical Administration Center, AFRITAC West) extensive technical assistance in the main areas of reform. This assistance, coupled with the policy advice on structural reforms provided in close collaboration with the World Bank, has contributed to building technical capacity and strengthening domestic institutions. 
Table 1. Mali: Quantitative Program Objectives and Outcomes, 2004-10

First program (2004-07)

\begin{tabular}{|c|c|c|c|c|c|}
\hline \multirow[t]{2}{*}{ Objective } & \multirow[t]{2}{*}{ Measure } & \multicolumn{4}{|c|}{ Outcomes (in percent) } \\
\hline & & 2004 & 2005 & 2006 & 2007 \\
\hline $\begin{array}{l}\text { Maintain macroeconomic } \\
\text { stability }\end{array}$ & $\begin{array}{l}\text { M-t budget deficit (payment order, excl. } \\
\text { grants) below } 7 \% \text { of GDP }\end{array}$ & -6.5 & -7.1 & -7.6 & -7.9 \\
\hline $\begin{array}{l}\text { Increase resources for poverty } \\
\text { reduction }\end{array}$ & $\begin{array}{l}\text { Bring tax revenue ratio closer to WAEMU } \\
\text { convergence criterion }(17 \% \text { GDP) }\end{array}$ & 14.9 & 15.4 & 14.9 & 14.2 \\
\hline $\begin{array}{l}\text { Increase budgetary allocation to } \\
\text { priority spending }\end{array}$ & Contain public wage bill at below 5\% GDP & 4.6 & 4.8 & 4.6 & 4.8 \\
\hline Keep inflation below 3\% & Monetary policy at regional level & -3.1 & 6.4 & 1.5 & 1.5 \\
\hline $\begin{array}{l}\text { Average GDP growth higher } \\
\text { than } 5 \% \text { per year }\end{array}$ & $\begin{array}{l}\text { Structural measures aimed at promoting } \\
\text { growth }\end{array}$ & 2.3 & 6.1 & 5.3 & 4.3 \\
\hline $\begin{array}{l}\text { Current account deficit (excl. } \\
\text { transfers) below } 7 \% \text { of GDP }\end{array}$ & $\begin{array}{l}\text { No specific measures } \\
\text { proposed }\end{array}$ & -9.8 & -10.6 & -6.7 & -9.5 \\
\hline \multicolumn{6}{|l|}{ Second program (2008-11) } \\
\hline \multirow[t]{2}{*}{ Objective } & Measure & \multicolumn{4}{|c|}{ Outcomes (in percent) } \\
\hline & & 2008 & 2009 & 2010 & \\
\hline $\begin{array}{l}\text { Reduce vulnerability to external } \\
\text { shocks; create fiscal space to } \\
\text { respond rapidly to ad-hoc } \\
\text { demands. }\end{array}$ & $\begin{array}{l}\text { Reduce basic fiscal deficit from } 1.1 \% \text { of } \\
\text { GDP in } 2008 \text { to } 1 \% \text { in } 2009 \text { and } 0 \% \text { of } \\
\text { GDP in } 2010^{7}\end{array}$ & -1.0 & -1.4 & -1.2 & \\
\hline $\begin{array}{l}\text { Increase resources for poverty } \\
\text { reduction }\end{array}$ & Stop downward trend in tax revenue & 13.3 & 14.7 & 14.7 & \\
\hline $\begin{array}{l}\text { M-t GDP growth should reach } \\
\text { ca. } 7 \% \text { per year }\end{array}$ & $\begin{array}{l}\text { Structural measures aimed at promoting } \\
\text { growth }\end{array}$ & 5.0 & 4.5 & 5.8 & \\
\hline $\begin{array}{l}\text { Current account deficit (excl. } \\
\text { grants) below } 7.5 \% \text { GDP }\end{array}$ & No specific measures proposed & -13.9 & -9.3 & -9.0 & \\
\hline
\end{tabular}

Source : IMF Staff reports.

\footnotetext{
${ }^{7}$ The objectives for the basic fiscal deficit were adjusted in 2009 to reflect the government's decision to use the exceptional resources from the privatization of SOTELMA for non-recurrent spending in 2010-2012 aimed at raising economic growth.
} 


\section{While Mali has succeeded in maintaining fiscal deficits at sustainable levels} (Figure 2), revenue performance did not improve during the program periods.

Although quantitative fiscal program conditions were generally met during 2004-10, the tax revenue-to-GDP ratio remained around 15 percent of GDP during 2004-10, lower than the average for WAEMU and sub-Saharan countries, despite revenue-enhancing reform efforts (Figure 3).
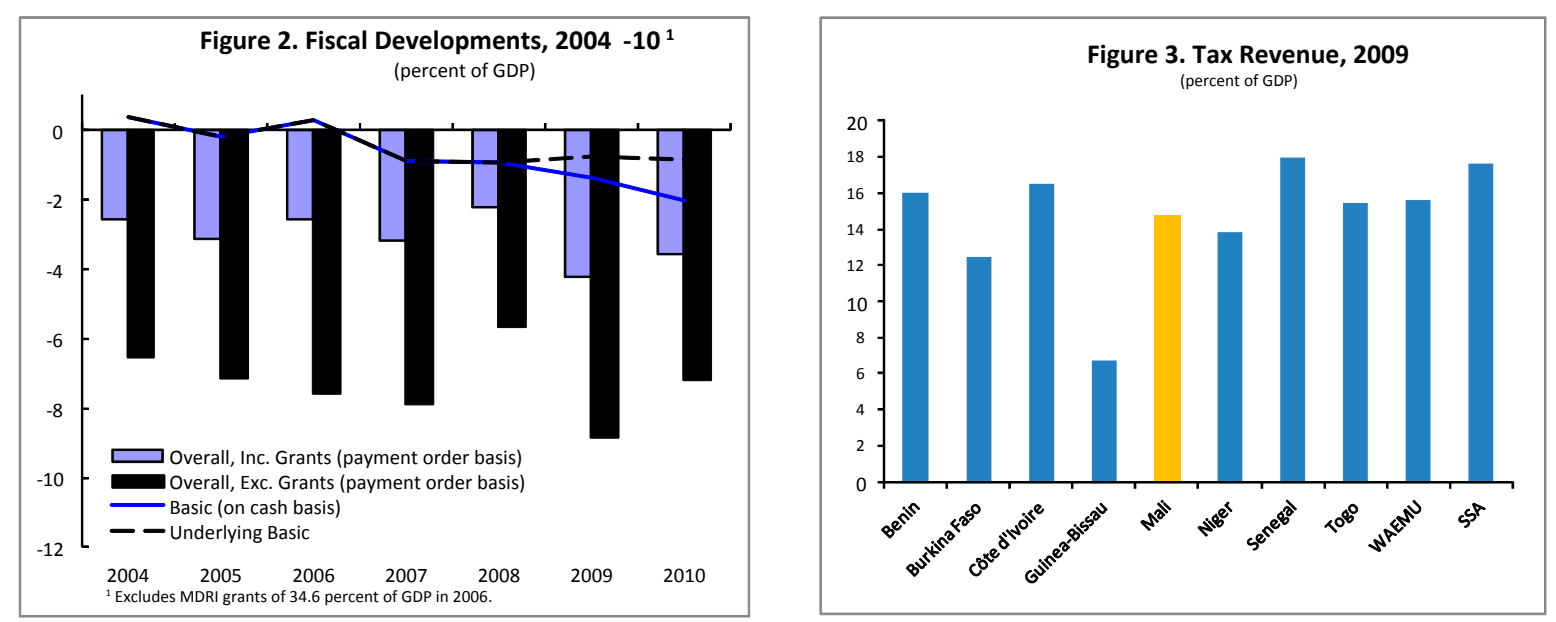

Source: WEO data base

\section{Priority social sector spending as a share of total spending increased from}

16.5 percent to 26.7 percent during 2006-10. This was in part due to increased poverty reduction spending resulting from the debt relief under the HIPC Initiative and MDRI. The programs placed some emphasis on aligning the composition of spending with PRSP objectives, highlighting a rising share of investment outlays. Nonetheless, the composition of public spending remained skewed towards recurrent outlays, reflecting increases in the wage bill and transfer payments and also problems in executing the externally financed investment program. As a result, public investment has not shown the increases needed to attract private investment, enhance economic growth, and meet the demands of rising demographic pressures (Figure 4).

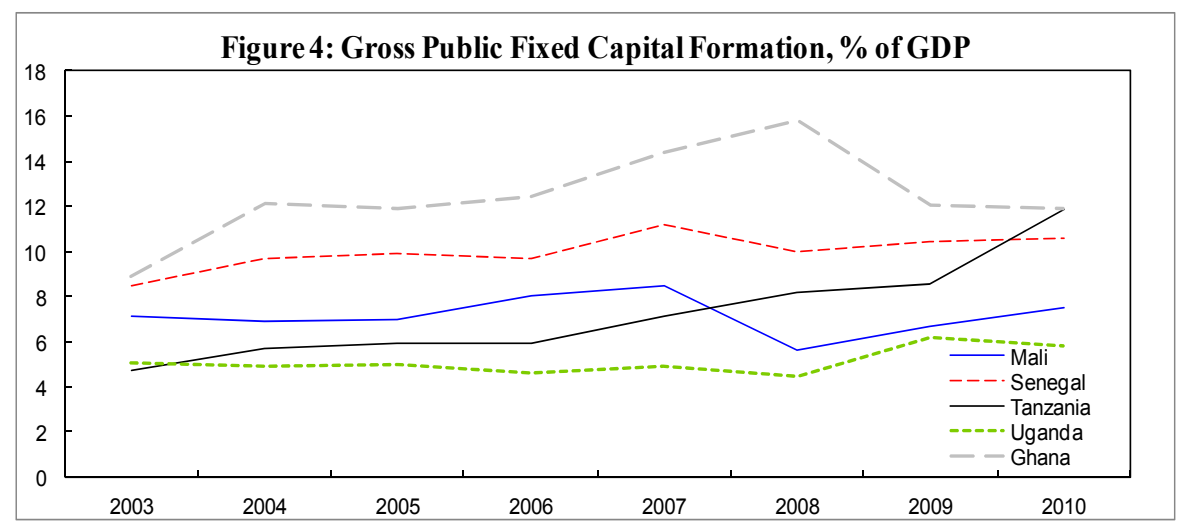

Source: WEO database 
17. Structural measures under the two programs were macro-critical, aiming to support the quantitative objectives and address Mali's weak growth performance and improve the living standards of the population. With a view to improving the business climate, promoting economic diversification, and stepping up infrastructure development, the authorities adopted an ambitious and comprehensive reform program. The main areas covered by structural measures and conditionality included tax policy and revenue administration; public financial management; the financial sector; the cotton sector; the electricity and telecom sectors; and private sector development and governance.

\section{Tax policy and revenue administration}

\section{Fund-supported programs aimed to improve tax collection and administration} by eliminating pervasive tax exemptions; simplifying the tax regime; strengthening the customs and tax administrations; adopting a pricing mechanism for petroleum products linked to world prices; and reinforcing VAT collection and reimbursements.

\section{Overall, progress has been slow, however, both in increasing tax collection and} in strengthening tax administration. While some progress was made (particularly during the second program) in enhancing the customs and tax administration, significant exemptions and weaknesses in bookkeeping of tax and customs revenues continue to undermine revenue performance. The tax regime has not been made more effective, and the authorities have been hesitant in establishing a new pricing mechanism for petroleum products. ${ }^{8}$ Finally, the government continued to accumulate VAT credit arrears due to the mining companies and their suppliers. In 2009, claims of two mining companies, equivalent to 1 percent of GDP, were settled through a combination of tax offsets and additional government borrowing from banks. However, further arrears have been accumulated since then. ${ }^{9}$

\section{Public financial management}

\section{On the other hand, Mali has made considerable progress in improving public} financial management (PFM). Under the first program the integrity of the spending chain

\footnotetext{
${ }^{8}$ The second arrangement included at the outset a continuous performance criterion on the maintenance of a minimum threshold for the taxation of oil products. In response to the 2008 food and fuel crisis, the authorities requested to drop this performance criterion at the first review under the PRGF/ECF arrangement. This performance criterion was subsequently dropped. In the context of the fifth review under the ECF, however, the government conducted a study of indexing gasoline prices at the pump to world prices. In December 2010, they adopted a pass-through mechanism of international oil prices to domestic prices, which they have started implementing in March 2011. The government also committed to developing an action plan by end-June 2011 that would modernize and simplify the tax legislation and bring it in line with the WAEMU directives within three years (structural benchmark for end-September 2011).
}

${ }^{9}$ In the context of the fifth review under the ECF, the authorities committed to reforming the VAT refund mechanism and the VAT regime by June 2011. 
(from payment orders to payment execution) was strengthened, and a joint database was created at the Budget and Treasury Directorates of the Ministry of Economy and Finance. The second program focused on the strengthening of budget preparation and execution, tightening financial controls, and improving public procurement. Under the program, the authorities are committed to implementing a number of measures aimed at establishing a Single Treasury Account, including by first making an inventory of government bank accounts at the commercial banks and the BCEAO. Mali expects to join the Extractive Industries Transparency Initiative (EITI) by end-2012.

\section{Notwithstanding these achievements, the PFM system continues to be}

characterized by weaknesses. A new reform program covering the period 2011-15 aims to improve cash management; increase the transparency and reliability of the accounting and financial data of the government; bring the legislative and regulatory framework for budget preparation and execution in line with WAEMU directives; and step up the fiscal deconcentration process. Also, to improve the coordination between the debt strategy and fiscal policy, the authorities are taking steps to advance the statistical coverage of domestic and external borrowing by government and public enterprises, as well as off-balance sheet items such as government guarantees for borrowing.

\section{Financial sector reform}

\section{The two programs included measures to deal with weak banks and promote}

financial sector reforms (Box 1). Measured by the share of credit to the private sector, Mali's banking system is still in its early stages of development: while the expansion of regional banks has contributed to diversifying the supply of banking services, credit to the economy as a share of GDP shows a slight decline over the period 2004-10, with an average of 18 percent. Reforms were implemented under the 2001-06 Financial Sector Development Strategy (FSDS), which was extended through 2008, and the FSDS for 2008-11. These included legal reforms, an increase in minimum capital requirement for banks (to CFAF 5 billion or about $\$ 10$ million), the development of the microfinance sector, and the restructuring of the non-bank financial sector. In 2008, Banque Internationale du Mali (BIM) was privatized successfully, albeit with delays. The restructuring of the housing bank (BHM), is under way, with the perspective to privatize this bank in 2012. Despite multiple recapitalizations and bail-outs since 2006 , the bank continues to face operating deficits and issues of corporate governance.

\section{The first program placed considerable emphasis on addressing the unsustainable deficits of the civil service pension fund (CRM) and the social security agency (INPS).} Following a 2005 actuarial study, a package of reforms to restore their financial health was proposed by the government in June 2006, but was never adopted by Parliament. In light of this, pension reform was not a prominent feature under the second program. Nonetheless, the authorities passed a pension reform law in July 2010, which replaced the CRM by a new entity, Caisse Malienne de Securité Sociale CMSS). A recently commissioned actuarial 
study indicated that unless reforms are implemented, the annual subsidy for the CMSS could increase from CFAF 34 billion (0.7 percent of GDP) in 2011 to CFAF 60 billion 0.9 percent of GDP) in 2015. In light of the results of this latest study, the government has submitted to Parliament a pension reform project whose adoption will reduce the deficit of the CMSS.

\section{Box 1. Mali: Financial Sector Development}

Mali's financial sector has undergone significant reforms under the two programs, but many challenges remain. The financial sector is dominated by banks, which represent about 90 percent of assets. In addition to 13 banks, the sector consists of 4 financial institutions, 2 pension funds, 6 insurance companies, and close to 480 microfinance institutions.

Reflecting the low degree of diversification of the economy, the banking sector is vulnerable to sector-specific shocks, in particular in the cotton sector, services, and energy, and is exposed to a limited number of large borrowers. Weaknesses include the legal framework; low market penetration and access; limited diversification of institutions and products; high intermediation costs; and limited expansion into rural areas and SMEs. Banks rely mainly on highly seasonal demand deposits for their financing, and financing of investment and real estate remain limited. To address some of these issues, the government approved in 2008 a 3-year Financial Sector Development Strategy (FSDS).

In general, the observance of prudential standards is satisfactory—overall numbers are affected by weaknesses in one bank (see Table below). The share of nonperforming loans is high, reflecting the fact that the recovery of claims is hampered by cumbersome legal procedures. Also, the significant expansion of the microfinance sector over the past few years has resulted in supervisory and governance challenges, and a rising share of NPLs.

\section{The main objectives of the 2008-11 FSDS are:}

- The consolidation of reforms and the strengthening and diversification of the financial sector

- Enhanced performance and quality of banks, non-bank financial institutions, and the microfinance sector

- Broader access to financial institutions and products, in particular in rural areas and for SMEs

- Development of medium- and long-term financing instruments, and a capital market

- Development of an efficient, modern payment system

- The continued restructuring and privatization of commercial banks, in particular BHM, and other financial institutions

- Improvements to the legislative framework (including a review of the land code, civil code, and commercial code) in line with FSAP 2008 recommendations.

Achievements under the FSDS to date have included amendments to the regulatory framework; the restructuring of Crédit Initiative S.A.; a study on the management structure for banks' real estate holdings; the adoption of plans for the management of government accounts; and launching the national action plan for the development of microfinance. 


\section{Box 1. Mali: Financial Sector Development (concluded)}

\section{Key Financial Sector Policies for 2011}

- Restructure BHM: The Ministry of Economy and Finance has prepared an assessment of the restructuring of the BHM, including the use of public funds transferred to the BHM during the first half of 2010, to re-launch the bank's lending activity with technical assistance from the World Bank and the Fund, with the aim to withdraw the government's equity stake by 2012 .

- Implement mechanisms to guarantee loans to SMEs, including a government fund (in the amount of CFAF 595 million) for partial guarantees during the period 2009-13. In addition to a study on a guarantee fund, the government has launched a study on an investment fund for the private sector, with results expected by November 2011.

- Establish an entity to manage banks' real estate holdings (the government-owned Property Transfer Agency ACI).

- Develop microfinance: Implement the national microfinance development plan.

Mali: Financial Soundness Indicators for the Banking Sector, 2004-10 ${ }^{1}$

\begin{tabular}{|c|c|c|c|c|c|c|c|}
\hline & 2004 & 2005 & 2006 & 2007 & 2008 & 2009 & 2010 \\
\hline \multicolumn{8}{|l|}{ Capital } \\
\hline Capital (net worth) in percent of assets & 7.4 & 9.7 & 9.2 & 7.2 & 7.4 & 8.7 & 11.3 \\
\hline \multicolumn{8}{|l|}{ Asset quality } \\
\hline Nonperforming loans in percent of total loans & 19.6 & 30.2 & 25.0 & 25.1 & 25.3 & 21.9 & 21.5 \\
\hline $\begin{array}{l}\text { Nonperforming loans net of provisions in percent of } \\
\text { total credits net of provisions }\end{array}$ & 9.9 & 16.3 & 12.6 & 10.7 & 9.3 & 9.1 & 8.9 \\
\hline Provisions as percent of nonperforming loans & 55.0 & 55.0 & 57.0 & 65.5 & 66.9 & 64.3 & 63.4 \\
\hline \multicolumn{8}{|l|}{ Earnings and profitability } \\
\hline Net profit (before tax) in percent of net income & -28.3 & 14.3 & 13.5 & -13.9 & 15.9 & 8.4 & 8.4 \\
\hline Return on equity & -22.6 & 8.7 & 8.7 & -12.1 & 13.3 & 13.2 & 13.2 \\
\hline Global margin (yield on loans minus cost of capital) & 6.2 & 6.5 & 7.0 & 7.3 & 7.9 & 9.0 & 9.0 \\
\hline \multicolumn{8}{|l|}{ Liquidity } \\
\hline Liquid assets/short term liabilities & 72.7 & 54.5 & 60.0 & 80.0 & 73.3 & 88.1 & 99.2 \\
\hline
\end{tabular}

Source: BCEAO, and IMF staff estimates.

${ }^{1}$ Ratios calculated on the basis of average stocks of the period.

\section{Reform of the cotton sector}

\section{The cotton sector is facing serious difficulties stemming mainly from sharp} swings in export prices for cotton fiber and a weak framework for input provision and marketing. With producer prices set without an explicit link to world prices, the public marketing and ginning company (CMDT) was frequently exposed to losses, requiring the government to provide financial assistance. To safeguard an important source of growth and 
income for the rural population, ${ }^{10}$ a reform strategy was adopted in 2003, supported by the Fund and the World Bank, with broad objectives to enhance the sector's efficiency and lower production costs, while also establishing a market-based price mechanism for the purchase of seed cotton to safeguard the budget.

25. Key components of the reform strategy were the establishment of a mechanism to link producer prices to world market prices and the privatization of the CMDT. The new pricing mechanism, however, was never put in practice because of resistance among stakeholders. The privatization of the CMDT was originally expected in 2006, then pushed back to 2008, and is now slated for 2011. A decisive turn was taken in 2009 with the splitting of CMDT in four regional monopsonies, to be eventually privatized, and the passage of a privatization law. The delay in the privatization of the CMDT was in large part caused by weak ownership among farmers and the CMDT.

\section{The privatization of the CMDT is a first step in a broader reform effort, of} which the key elements have been outlined only recently. In August 2010, the government adopted the outlines of an action plan for 2010-15, aimed at promoting growth in the cotton sector. Further actions will be needed to put this plan into practice (see Box 2).

\section{Reform of the utilities}

27. The two programs were only partially successful in addressing the problems of the utility sector (electricity and telecommunications). With less than 20 percent of the population having access to electricity and only 0.7 percent to fixed telephone connections, the country's development needs in this area are very large. The purpose of the government's reform efforts in the utility sector has been twofold: improve the infrastructure through increased private sector investment; and mitigate the risks to the government's budget emanating from recurrent operating losses. While the privatization of a majority share in the telecommunications company (SOTELMA) was completed in 2009 (albeit with significant delays), efforts to rehabilitate the electricity company (EDM) have met with serious difficulties. In fact, the privatization of EDM, which was completed in 2000, was reversed in 2005 following a dispute over tariff-setting and investment levels with the private owners.

\footnotetext{
${ }^{10}$ Mali is the second largest cotton producer in Sub-Saharan Africa after Burkina Faso. About one quarter of the population depends on cotton for its livelihood. In 2010, cotton represented around 2 percent of the country's nominal GDP and about 8 percent of its exports. The cotton season runs from June to May (sowing in May-June, harvesting in October-November, total production collection and payment to producers normally completed by April-May of the following year, and shipment of ginned cotton normally completed by the summer).
} 


\section{Box 2. Reform of the Cotton Sector}

Privatization of the CMDT is a first step toward higher efficiency in production and reducing uncertainties stemming from volatility in international cotton prices. Mali's economic development banks on solid growth in agriculture over the medium term, including a post-privatization expansion of cotton production. To achieve higher efficiency and lower unit costs for ginning, productivity gains will be needed at the new private companies that will be regional monopsonies. There will be no competition among these companies for seed cotton, as measures will be devised to prevent "side sales" of cotton by farmers. The rationale for this structure is the need to maintain the delivery and payment of fertilizers (possibly subsidized by the budget) under the control of the regional ginneries. There is a risk that little would be gained in replacing a public monopsony with private monopsonies, besides the possibility of comparing the performance of regional companies and setting benchmarks.

The government is implementing a plan to re-launch cotton production. The actions include an increase in domestic producer prices to reflect higher world market prices; the provision of input subsidies; and making progress towards a framework to resolve the debt overhang of producer organizations. Steps are also being taken to render the recently established Cotton Inter-professional Association (CIPC) operational. Over the medium term, the government will continue to strengthen capacity in bio-safety regulation in research activities in the cotton sector.

Given the social and political importance of the cotton sector, the monitoring of the social impact of developments in the cotton sector is clearly of interest to the government. There may be a risk of costly government intervention if the international market for cotton deteriorates sharply, which calls for continuing monitoring postprivatization.

28. The reduction and subsequent freezing of electricity tariffs in 2004 has left EDM in an unsustainable financial position, notwithstanding a modest rate increase in 2009. ${ }^{11}$ Although EDM's situation has been manageable at the technical level of operations, with electricity distribution losses high but stable at about 20 percent, financial losses are accumulating. Short-term debt with local banks has increased rapidly; in addition, arrears to oil suppliers have piled up. Costs to the government have arisen mainly through non-transparent ad-hoc tax rebates and operating subsidies. ${ }^{12}$ EDM tariffs are lower than in Senegal and Burkina Faso, which rely more on thermal plants, but higher than in Ivory Coast and Ghana.

\footnotetext{
${ }^{11}$ Electricity rates were increased by 5 percent in 2009.

${ }^{12}$ There was a budget subsidy in 2008, but none in 2009 and 2010.
} 


\section{Private sector development and governance}

29. Notwithstanding progress toward a more favorable business climate in recent years, especially in comparison with other sub-Saharan African countries, private sector development remains a challenge. Mali ranked 132 out of 139 countries in the World Economic Forum's 2010-11 Global Competitiveness Index, and 153 out of 183 countries in the World Bank's Doing Business Indicators 2010 (Table 2). The scores are particularly weak on getting credit, ease of doing business, international trade, and paying taxes. Tax rates on profits are well above levels in neighboring countries. Mali has also serious governance problems: in the Transparency International Corruption Perceptions Index 2010, it ranked 116 out of 176 countries.

Table 2. Mali: Selected Doing Business Indicators, 2010 and 2011(Rank)

\begin{tabular}{lcc}
\hline Rank & $\mathbf{2 0 1 0}$ & $\mathbf{2 0 1 1}$ \\
\hline Starting a business & 139 & 117 \\
Dealing with construction permits & 94 & 87 \\
Registering property & 99 & 88 \\
Getting credit & 150 & 152 \\
Protecting investors & 147 & 147 \\
Paying taxes & 158 & 159 \\
Trading across borders & 156 & 154 \\
Enforcing contracts & 135 & 133 \\
Closing a business & 117 & 106 \\
\hline
\end{tabular}

Source: World Bank, Doing Business Indicators, http://www.doingbusiness.org/data/exploreeconomies/mali

30. These rankings explain in part the relatively low private investment ratio. As shown in Figure 5, private investment as a share of GDP has declined during the past decade, and lies well below the levels in other countries in sub-Saharan Africa. While other factors may be playing a role as well, including Mali's geographical position, problems with doing business, including governance issues, are a major impediment to higher investment, economic growth, and employment.

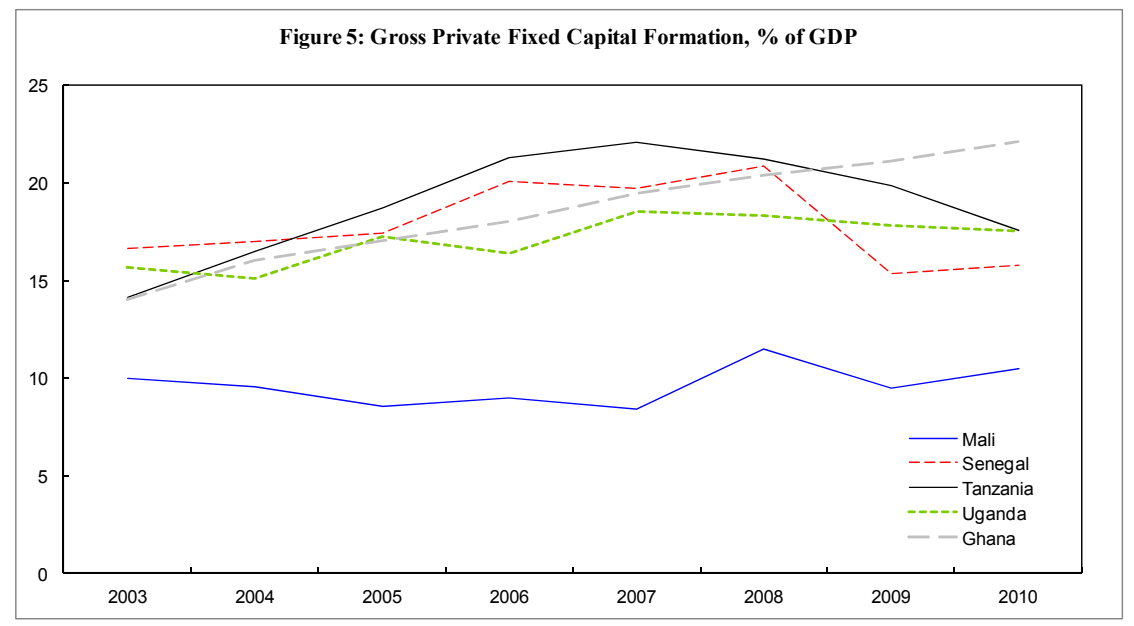

Source: WEO database

CInternational Monetary Fund. Not for Redistribution 
31. A comparison with other sub-Saharan African countries illustrates the importance of a good business climate for private investment and growth. Ghana, for instance, experienced an annual growth rate of about 6 percent in the past decade, driven by a relatively high and rising level of private investment: in 2010, Ghana's private investment/GDP ratio was about double the ratio in Mali. Ghana has made much progress in improving its business climate over the years, as evidenced by its high rankings in Doing Business. In 2011, Ghana ranked 44 on access to credit, 89 on international trade, and 78 on paying taxes.

\section{Fund-supported programs have aimed at supporting the authorities' efforts to} reduce the impediments to private sector development. Policy recommendations included enhancing competitiveness through better infrastructure; streamlining the regulatory framework; strengthening the judicial system and governance; and improving labor skills and productivity. In 2006, the authorities established a one-stop shop for new investors, simplifying the process for establishing an enterprise considerably. They are now implementing the 2009 action plan to improve the business climate and enhance private sector competitiveness. The review of the Investment Code is under way, with World Bank support, and the Private Sector Framework Law was adopted by the Council of Ministers in December 2010.

\section{B. Poverty Reduction and Social policy}

\section{Mali's policies to reduce poverty have been embedded in Fund programs} through the PRSP for 2002-06 and the G-PRSP for 2007-11. Despite some progress toward the reduction of poverty, Mali's social indicators are among the lowest in the world, with limited prospects for achieving the Millennium Development Goals (MDGs) by 2015 (Figure 6). A key objective of the poverty reduction strategy is to support economic growth through institutional development and improved governance; strengthened access to basic social services; the development of infrastructure; and support for key productive sectors. Fund programs have aimed to ensure coherence between the annual budget and the mediumterm expenditure framework for poverty reduction spending under the PRSP and G-PRSP.

\section{Poverty correlates strongly with world market and regional prices for food. In} response to the fuel and food price shocks in 2008, the government pursued a series of interventions, such as subsidies for fertilizer and agricultural machinery, a temporary export ban on grain, the lifting of import taxes on some food items, and a temporary reduction in petroleum taxes with a total impact in lost revenue of 1.8 percent of GDP. The 2008 Progress Report on the PRSP noted that some of these measures had not been well targeted and did not contribute to protecting the poor. ${ }^{13}$

\footnotetext{
${ }^{13}$ http://www.imf.org/external/pubs/cat/longres.aspx? sk=24619.0
} 
Figure 6. Mali: Selected Millennium Development Goals, 1990-2015
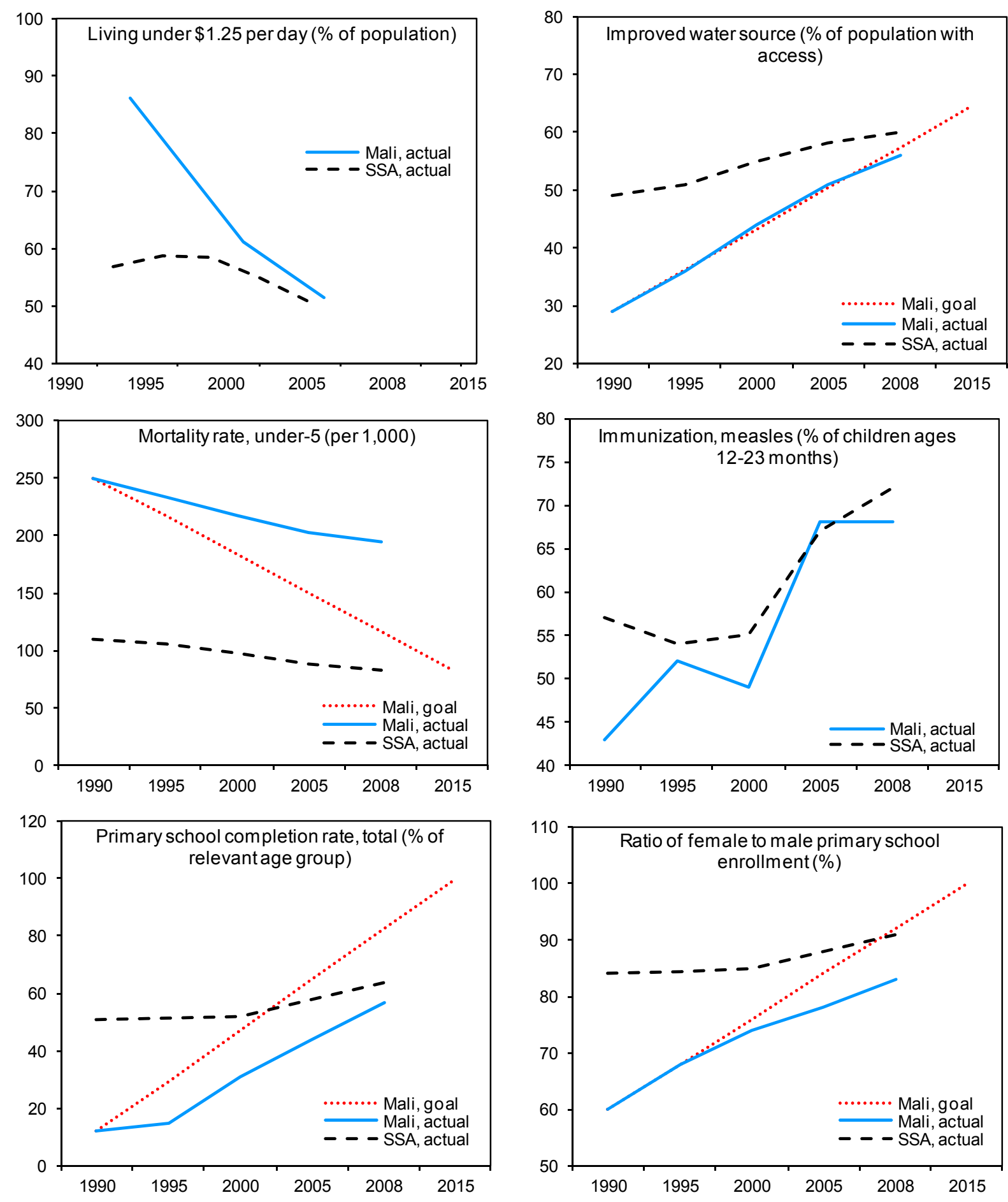

Source: The World Bank, Millennium Development Goals database, 2010 


\section{Program Conditionality}

35. While quantitative program conditions were generally met during 2004-10, the observance of structural conditionality was mixed (Tables 3 and 4). Implementation of structural reforms under the 2004-07 program was generally disappointing, and a substantial number of program conditions were either not met or met with considerable delay. Besides the delays in reforming the cotton and electricity sectors, the benchmark on completing the recapitalization of BHM was not met. The pension reform was gradually put off. Efforts to link petroleum product prices to world market prices were not consistently pursued. A bright spot was the completion of the project integrating the budgetary spending chain until the payments stage.

\section{Implementation of structural reforms and the observance of related} conditionality improved notably during the 2008-11 program. This reflected greater ownership and the streamlining of the reform agenda, with a reduction in the number of program conditions (from 39 to 23), particularly in the area of budgetary expenditure control, pension reform and privatization. By end-2010, the structural reform agenda was progressing, with a strengthening of public finance management in 2010, and the restructuring of the BHM, with a view to privatizing it in 2012.

\section{Collaboration with the World Bank}

37. Bank-Fund collaboration has been effective during the two programs. The IMF has taken the lead in macroeconomic stabilization and the World Bank in social and structural reforms, with close collaboration on a few structural areas that have a particular impact on macroeconomic stability. In particular, the Bank has taken the lead in structural areas where both institutions had conditionality, including cotton sector reform, privatization and regulatory reform (telecommunications, banking, energy sectors), and pension reform.

\section{E. Concluding Remarks on the Effectiveness of the Programs}

38. The above discussion leads to the conclusion that the two programs were only partially effective in achieving core objectives. The objective of macroeconomic stability was achieved, as evidenced by the moderate fiscal deficits, low and relatively stable rates of inflation, and - helped by HIPC/MDRI debt relief - the maintenance of a sustainable external debt position. The programs have also been effective in supporting financial stability. 


\section{Quantitative Performance Criteria}

Net domestic financing of the government

Cumulative change in government external payments arrears 1/

M

M

New external borrowing at terms of one year or more contracted or guaranteed by the governmnet on nonconcessional terms 1 /

New short-term external debt (less than one year) contracted or guaranteed by the government $1 / 2$ /

\section{Financial Performance Indicators}

Cumulative tax revenue

Cumulative wage bill

Overall basic fiscal balance

M

M

$M-M$

M

M

M

M

M

M

M

M

M

M

M

M

M

M

$\begin{array}{ll}M & M \\ M & M\end{array}$

$M \quad M$

$\begin{array}{lccc}M & \text { NM } & \text { NM } & M \\ M & \text { NM } & \text { M } & M \\ M & \text { NM } & \text { NM } & M\end{array}$

$M$

$M$

$M$

NM

$\mathrm{M}$

$\mathrm{M}$

2008-2010

$\begin{array}{llllll}\text { Jun. } 2008 & \text { Dec. } 2008 & \text { Jun. } 2009 & \text { Dec. } 2009 & \text { Jun. } 2010 & \text { Dec. } 2010\end{array}$

\section{Quantitative Performance Criteria 1/}

Net domestic financing of the government (ceiling)

Bank and market financing

$\begin{array}{llllll}M & M & M & M & M & M \\ M & M & M & M & M & M \\ M & M & M & M & M & M\end{array}$

Cumulative increase in external payments arrears

(ceiling) $2 /$

New external borrowing at terms of one year or more contracted or guaranteed by the governmnet on nonconcessional terms 2 I

M

$M \quad M$

M M

contracted or guaranteed by the government $2 /$

Net tax revenue

Financial Performance Indicators (floors)

Basic fiscal balance

Basic fiscal balance, underlying (floor)

Priority spending (floor)

Net tax revenue

Source: IMF Staff reports

$\mathrm{M}=$ Met, $\mathrm{NM}=$ Not met

$1 /$ Monitored on a continuous basis

2/ Excluding import-related credit and CMDT borrowing from foreign banks secured by proceeds of cotton exports, debt relief 
39. The two programs, however, did not succeed in raising growth or addressing the vulnerabilities emanating from a largely agrarian economy and high dependence on gold exports. This is worrisome, because growth is essential for poverty reduction and making progress towards the MDGs. Public and private investment ratios remain too low, and notwithstanding progress in recent years, Mali continues to rank among the countries with the least attractive business climate. Closely related to this, limited progress has been made in diversifying the economy and reducing Mali' dependence on rain-fed agriculture and gold exports.

40. While growth-oriented structural measures under the two programs were in general well targeted, their implementation was uneven and often subject to delays. In key areas of the structural reform agenda, measures were implemented over a much longer time period than initially foreseen, and in some cases reform objectives appear to have been abandoned. For instance, delays in the reform of the tax system and the lack of progress in eliminating tax exemptions in the past seven years have much contributed to the failure to bolster revenue performance_crucial for creating fiscal space for development spending. Similarly, the strengthening of the financial positions of the CRM and the INPS - a key objective under the 2004-07 program — was not achieved.

\section{In some cases, the question can be asked whether program measures addressed} the problems. In particular, it is not clear how the split-up into regional monopsonies and subsequent privatization of the CMDT - a subject of conditionality under both programswill address key problems affecting the cotton sector, such as how to protect farmers' incomes during periods of low international cotton prices or non-repayment of crop credit. Without additional reforms to address these problems, the unstable conditions that currently characterize this sector — with risks for the government budget — are likely to persist. Similarly, the aim to privatize the BHM may not be feasible without concrete measures to put the bank on a sound footing.

\section{The slow implementation of structural reforms may be primarily the reflection} of a lack of ownership of key stakeholders. The often hesitant attitude of the government towards reform measures seems to be rooted in a strong tradition of political consensusseeking and an attachment to the role of the state in the economy. For instance, the pace of reforms of public sector entities, such as the CMDT and SOTELMA, was affected by reluctance to reduce the role of the government and concerns over the implications for the workers at these enterprises. Although these social concerns are legitimate, there may have been merit in creating a greater sense of urgency with regard to the reform program, including through more effective consensus-building outreach efforts. 
43. Given the complexity of many of the reforms, implementation capacity constraints in public administration also played a significant role. The administrative capacity of the authorities may have been too thin to manage simultaneous reforms in many areas.

\section{Medium-Term Policy Challenges}

44. Mali is a country with daunting development challenges, requiring exceptional reform efforts by the government. The authorities have indicated that they would like to continue their endeavor to raise growth in the context of a Fund-supported program (Annex 2). As the Fund has a key role in supporting these efforts, there is a strong case for continued program engagement in the context of the ECF. Given Mali's large external financing requirements and the importance of structural measures in an effective program, it is too early to consider the Policy Support Instrument (PSI) or alternative facilities for low-income countries, such as the Short-Term Credit Facility (SCF). Many of the steps in the reform process needed to bring Mali on a higher growth path, such as fiscal reforms, the privatization of state-owned enterprises, and strengthening the financial sector, are already included in the current program supported by the ECF. A new Fund-supported program would underpin recent progress, and constitute a framework for further, more rapid progress in these areas. In addition, Fund support has an important catalytical role in generating donor support. Mali will remain highly dependent on external donor support in the foreseeable future, especially also in light of the public expenditure pressures emanating from the social needs of a rapidly rising and relatively young population.

\section{Stepping up the reform effort is also urgent because of the uncertainties} surrounding the medium-term prospects for gold production. With current reserves estimated at 350 metric tons and an annual production of about 50 tons, production of existing gold mines will start declining soon. Although new explorations for gold and other minerals are ongoing, there is much uncertainty about the development of the mining sector over the medium and long term. In addition, while gold exports constitute an important source of government revenue (about 20 percent of total revenue), the backward linkages of the gold mining industry to the domestic economy are limited, as the production process is capital-intensive and a large share of the inputs is imported ${ }^{14}$. These circumstances underline the need to make rapid progress in diversifying the economy and broadening the tax base.

46. The mixed progress in reforming the economy in recent years has underscored the need to take ownership issues and implementation capacity constraints explicitly into account when formulating the reform program. To ensure the success of a new

\footnotetext{
${ }^{14}$ Mali is the third-largest gold producer in Sub Saharan Africa, after South Africa and Ghana. The share of the gold sector in GDP has grown from 2 percent in 1995 to 6 percent in 2010, and accounts for about three quarters of exports. The sector, however, employs less than 1 percent of the work force.
} 
program, the government should consider stepping up its outreach efforts to foster acceptance of the need for reforms among the main stakeholders and opinion makers. Also, given the limits to the capacity of the administration to manage structural reforms and public investment, a future program - and structural conditionality - should focus on those measures that have the highest pay-off in terms of promoting macroeconomic stability and growth.

\section{Building on the progress made under the current program, a future Fund-supported program could focus on the following priorities:}

\section{Maintaining macroeconomic and financial stability}

47. Maintaining macroeconomic stability should remain a core objective of a future Fund-supported program. To reduce fiscal vulnerabilities, a new program should include measures to protect the government budget from the unsustainable financial deficits of major public entities, in particular, the CMSS well as the EDM.

\section{Further steps should be taken to promote financial stability and development.}

Although most banks meet key prudential standards, their high dependence on a few sectors in the economy-mainly public entities and the cotton sector-are a source of concern. To reduce vulnerabilities, it will be important to make progress in implementing the government's reform program for the financial sector, and put the housing bank on a sound financial footing to ready it for privatization by 2012. Diversification of banks' loan portfolios and the development of access by small and medium-sized companies to bank credit need to be supported by significant headway in the definition and enforcement of property rights; a strengthening of the judicial system; deepening credit information; and extending credit registry coverage. High priority should be given to the strengthening of the microfinance sector.

\section{Structural measures to raise the living standards of the Malian people.}

49. Mali needs higher, inclusive economic growth to improve the well being of the Malian people, especially the poorest, create jobs for a rapidly rising labor population, and reduce vulnerability. To achieve these multiple objectives, it will be important to diversify the economy in sectors that have the highest impact on employment and poverty reduction, such as agriculture, services, and labor-intensive manufacturing. A new Fundsupported program should focus on those measures within the mandate of the Fund that help create the conditions for rapid progress:

Stepping up public infrastructure investment and raising the effectiveness of public spending. Higher economic growth cannot be achieved without large public investments to upgrade Mali's economic and physical infrastructure, including the modernization of water and energy supply, the telecommunication networks, and the transportation system. To 
achieve this, a new medium-term Fund-supported program could focus on policy actions (supported by technical assistance if needed) in several key areas:

- $\quad$ Strengthening project selection and implementation capacity in line ministries. As a first step, the authorities could consider to strengthen their analytical capabilities to assess the viability of investment projects. At the same time, line ministries could be reorganized to strengthen the monitoring and implementation of investment projects.

- $\quad$ A strong commitment on the part of the authorities is needed to raise domestic resources by improving tax revenue. Though the challenges are substantial, progress can be made. Mali requires significant resources to achieve its Millennium Development Goals and increase its public infrastructure investment. Eliminating existing exemptions will be a major step forward. Also, concerted efforts are needed to simplify and streamline the tax code, modernize the tax and customs administration, widen the tax base, strengthen the large-and medium-size tax payer's offices, and improve book keeping of tax and customs revenues. Finally, a successful strategy would require a transparent and non-discretionary system for revenue mobilization.

- $\quad$ Steps are being taken to further strengthen public financial management, to increase the effectiveness of spending (including improving its composition), and create favorable conditions for higher donor aid. A new program should continue to support these efforts, giving high priority to strengthening budget execution, improving debt and cash-flow management, and reforming the reimbursement of VAT credits.

- $\quad$ At the same time, the government should-supported by technical assistance if needed-explore options for involving the private sector in public investment projects, including through management concessions and other forms of public-private partnership. Contingent budget liabilities related to public-private partnerships should be capped and closely monitored.

Creating the conditions for higher private investment. Increased infrastructure investment will need to be complemented by other policy actions to enhance Mali's attractiveness as a place to invest by the private sector. While action will be required on many fronts, the following areas warrant special attention in the context of a new Fund-supported program:

- An effective reform of the tax system should not only strengthen revenue performance, but also render the tax system more business friendly. In this regard, the government should consider a reduction in taxes on profits, while increasing tax revenue through a considerable widening of the tax base, and simplify the tax system in order to reduce the administrative burden on companies.

- $\quad$ Further policy actions will be needed to improve access to credit for small and medium-sized companies, not only by strengthening the microfinance sector, but also by improving the conditions for commercial banking sector development - as outlined aboveand financial markets. 
50. Finally, to reduce budgetary risks the reform of the cotton sector will need to be closely monitored under a new program. As noted above, while the privatization of the CMDT is an important first step in the reform process, further actions will be needed to create a stable and viable framework for input provision and cotton marketing by setting up a government supervisory board. Without such a framework, the government will likely be facing new pressures to provide financial support in the coming years. 
Mali: Selected Economic and Financial Indicators, 2008-11

\begin{tabular}{|c|c|c|c|c|c|c|}
\hline & \multirow[t]{2}{*}{2008} & \multirow[t]{2}{*}{2009} & \multicolumn{2}{|c|}{2010} & \multicolumn{2}{|c|}{2011} \\
\hline & & & Prog ${ }^{1}$ & $\overline{\text { Est. }}$ & Prog. $^{2}$ & Rev. \\
\hline & \multicolumn{6}{|c|}{ (annual percentage change) } \\
\hline \multicolumn{7}{|l|}{ National income and prices } \\
\hline Real GDP & 5.0 & 4.5 & 5.1 & 5.8 & 6.0 & 5.3 \\
\hline GDP deflator & 8.8 & 3.6 & 3.6 & 3.6 & 3.6 & 4.4 \\
\hline Consumer price inflation (average) & 9.1 & 2.2 & 2.1 & 1.4 & 2.0 & 3.5 \\
\hline \multicolumn{7}{|l|}{ External sector (percent change) } \\
\hline Terms of trade (deterioration -) & 32.7 & 8.3 & 6.6 & -1.3 & 5.1 & 12.7 \\
\hline Real effective exchange rate (depreciation -) & 8.0 & 0.3 & $\ldots$ & -6.3 & $\ldots$ & $\ldots$ \\
\hline \multicolumn{7}{|l|}{ Money and credit (contribution to broad money growth) } \\
\hline Credit to the government & -3.2 & -13.9 & 10.4 & 2.5 & 6.0 & 6.1 \\
\hline Credit to the economy & 5.2 & 7.2 & 5.7 & 8.4 & 3.1 & 8.5 \\
\hline Broad money (M2) & 0.5 & 16.0 & 16.7 & 8.9 & 11.5 & 10.8 \\
\hline & \multicolumn{6}{|c|}{ (in percent of GDP, unless otherwise indicated) } \\
\hline \multicolumn{7}{|l|}{ Investment and saving } \\
\hline Gross domestic investment & 19.0 & 20.3 & 20.0 & 18.4 & 19.3 & 20.4 \\
\hline Of which: government & 7.5 & 10.8 & 7.5 & 7.9 & 7.8 & 8.9 \\
\hline Gross national savings & 6.3 & 12.9 & 12.1 & 10.9 & 11.3 & 12.6 \\
\hline Of which: government & 0.6 & 0.5 & 1.5 & 1.6 & -0.6 & 2.3 \\
\hline Gross domestic savings & 4.7 & 12.7 & 10.3 & 9.7 & 12.4 & 12.8 \\
\hline \multicolumn{7}{|l|}{ Central government finance } \\
\hline Revenue & 15.5 & 17.1 & 16.9 & 17.4 & 16.4 & 16.7 \\
\hline Grants & 3.4 & 4.6 & 3.9 & 2.9 & 4.7 & 3.3 \\
\hline Total expenditure and net lending & 21.2 & 25.9 & 25.5 & 22.9 & 25.4 & 24.2 \\
\hline Overall balance (payment order basis, including grants) & -2.2 & -4.2 & -4.6 & -2.6 & -4.3 & -4.2 \\
\hline Basic fiscal balance ${ }^{3}$ & -1.0 & -1.4 & -2.4 & -1.2 & -2.0 & -2.5 \\
\hline Underlying basic fiscal balance ${ }^{4}$ & -1.0 & -0.8 & -1.1 & -0.4 & -1.3 & -1.4 \\
\hline Domestic debt ${ }^{5}$ & 2.5 & 3.0 & 2.0 & 3.6 & 3.7 & 3.7 \\
\hline \multicolumn{7}{|l|}{ External sector } \\
\hline Current external balance (including official transfers) & -12.7 & -7.3 & -7.9 & -7.5 & -8.0 & -7.7 \\
\hline Current external balance (excluding official transfers) & -13.9 & -9.3 & -10.2 & -9.0 & -9.1 & -9.0 \\
\hline Exports of goods and services & 28.7 & 26.2 & 28.9 & 24.7 & 29.5 & 26.8 \\
\hline Imports of goods and services & 43.0 & 33.8 & 38.5 & 33.4 & 36.5 & 34.3 \\
\hline Debt service to exports of goods and services & 3.7 & 4.1 & 3.7 & 2.9 & 1.8 & 3.2 \\
\hline External debt & 19.1 & 21.2 & 24.2 & 24.2 & 26.1 & 23.8 \\
\hline \multicolumn{7}{|l|}{ Memorandum items: } \\
\hline Nominal GDP (CFAF billions) & 3,913 & 4,233 & 4,609 & 4,642 & 5,032 & 5,104 \\
\hline Overall balance of payments (US\$ millions) & -9.9 & 445.9 & -44.1 & -174.4 & 36.6 & -102.9 \\
\hline Money market interest rate in percent (end of period) & 6.0 & 4.0 & $\ldots$ & 4.1 & $\ldots$ & $\ldots$ \\
\hline \multicolumn{7}{|l|}{ Gross international reserves (US\$ millions) } \\
\hline Central Bank of West African States (BCEAO) & 11,300 & 13,200 & $\ldots$ & 12,875 & $\ldots$ & $\ldots$ \\
\hline in percent of broad money & 56.0 & 69.3 & $\ldots$ & 57.9 & $\ldots$ & $\ldots$ \\
\hline in months of imports of g. and s. & 5.8 & 6.5 & $\ldots$ & 6.1 & $\ldots$ & $\ldots$ \\
\hline BCEAO Mali (imputed) ${ }^{6}$ & 1,033 & 1,602 & 1,389 & 1,295 & 1,435 & 1,240 \\
\hline in percent of broad money & 48.6 & 60.6 & 51.5 & 49.7 & 48.9 & 41.5 \\
\hline US\$ exchange rate (end of period) & 481.5 & 449.3 & $\ldots$ & 496.2 & $\ldots$ & $\ldots$ \\
\hline Gold Price (US\$/fine ounce London fix) & 872 & 973 & 1,183 & 1,225 & 1,221 & 1,427 \\
\hline Petroleum price (crude spot)(US\$/bbl) & 97.0 & 61.8 & 78.3 & 79.0 & 78.8 & 107.2 \\
\hline
\end{tabular}

Sources: Ministry of Finance; and IMF staff estimates and projections.

${ }^{1}$ IMF Country Report No. 10/255: Mali —Article IV Consultation and Fourth Review Under the ECF.

${ }^{2}$ IMF Country Report No. 11/37: Mali -Fifth Review Under the ECF.

${ }^{3}$ Revenue excluding grants minus domestically financed expenditure.

${ }^{4}$ Basic fiscal balance excluding spending financed by the revenue from the privatization of the telecom company SOTELMA.

${ }^{5}$ Includes BCEAO statutory advances, government bonds, treasury bills, and other debts.

${ }^{6}$ For 2009 , reflects new SDR allocation and privatization receipts of SOTELMA.

\section{(CInternational Monetary Fund. Not for Redistribution}




\section{COMMENTS OF THE GOVERNMENT OF MALI ON THE REPORT ASSESSING MALI'S COOPERATION PROGRAMS (2004-2011) WITH THE IMF}

\section{UNDERSTANDING THE REPORT}

1. The last decade's cooperation program with the International Monetary Fund (IMF) comprised two periods: the Poverty Reduction and Growth Facility (PRGF) arrangement approved in June 2004, of which the 6th and final review was completed in October 2007; and the PRGF/Extended Credit Facility (ECF) arrangement approved in May 2008, which was extended through December 2011. To assess these two programs, the IMF assigned a team of experts to take stock of the various reform programs.

2. The report submitted for the opinion of the Malian authorities first summarizes the macroeconomic trends of the 2004-2010 period and then discusses the authorities' main objectives under the programs, how they were to be achieved, and their effectiveness. The report concludes with a discussion of medium-term economic challenges and priorities for a possible future IMF program.

3. The report expresses concern about the low level of GDP growth and the vulnerability of the Malian economy, linked to the essentially agrarian nature of the economic base and the country's heavy reliance on gold exports. The public and private investment ratios remain too low, and despite the progress achieved in recent years, Mali continues to rank among the countries with the least attractive business climate. According to the report, stepping up reform efforts is essential, owing to the uncertainties surrounding the medium-term prospects for gold. The report also underscores the lack of ownership and capacities for implementing reforms.

4. The report expresses concern about the ineffectiveness of the Malian tax system. It identifies discretionary exemptions and weaknesses in the recording of tax and customs revenue, which undermines revenue performance. The report mentions difficulties in managing VAT credits. Despite progress in public financial management, the report emphasizes that the frequent accumulation of domestic payments arrears is linked to cash management problems. 
5. The conclusions of the report indicate that the two programs were only partially effective in achieving core objectives, namely macroeconomic stability with a low level of fiscal deficits, control of inflation, and the maintenance of a sustainable external debt position.

\section{OPINIONS AND COMMENTS}

6. During the high-level conference held in Bamako on March 17 and 18, 2001, the participants agreed on the need to strengthen policies fostering stronger economic growth and job creation, as well as poverty reduction. The participants emphasized the need to improve public financial management and the business climate, promote greater diversification of the economy, boost productivity in key sectors such as agriculture, promote education and vocational training for young people, and strengthen regional integration.

7. The participants focused in particular on the business climate, which is not conducive to industrial growth and diversification of the economy. The constraints in this area include a burdensome tax system, the difficulties of accessing bank credit, and the high cost of inputs. They also noted that satisfying the rapidly growing demand for jobs calls for measures aimed at promoting the private sector, in particular by enhancing legal security and deepening financial intermediation.

8. The participants expressed concern about the low tax ratio (15 percent). The challenge is to broaden the tax base and lighten the tax burden, which remains concentrated on a small number of economic operators. Improving the tax system would boost the level of domestic financing and, consequently, promote investment for self-financed sustainable growth.

9. Education and vocational training also drew the attention of the participants. They expressed concern about the current quality of education. The challenge in this area is to identify a type of education that is geared toward employment and vocational training.

10. The conference provided an opportunity for productive discussions on the challenges posed by the strong demographic growth observed in recent years in Mali. In terms of achieving the Millennium Development Goals, the stakes involved in this significant growth are numerous. To combat poverty, demographic growth should be matched by economic growth. The conference looked forward to the participation of various technical and financial partners in financing the Population Priority Investment Policy.

11. The government generally concurs with the conclusions of the report. However, it should be noted that the assessment of the Malian tax system does not take account of the reality of the current situation. Indeed, although the volume of exemptions in 
government revenue remains high, most of these exemptions are related either to imports of capital goods for projects in the investment phase and thus provided for in the relevant financing agreements, or to the expenses of diplomatic missions, also provided for in their charters. The discretionary exemptions are generally related to extraordinary measures adopted by the government to import certain basic necessities during crisis periods to ensure that such products are available to vulnerable segments of the population.

12. Reforms are under way to implement the WAEMU directives on tax transitions. With IMF and World Bank technical assistance, the Ministry of Economy and Finance has undertaken a number of reforms of the tax and customs administrations that have enabled those agencies to achieve encouraging results in recent years. The government is resolutely determined to pursue its reforms to further enhance the effectiveness and efficiency of tax and customs administration.

13. The government is committed to implementing policies designed to promote stronger economic growth that creates more jobs. The previous programs were generally aimed at fiscal targets with the underlying assumption that attaining them would have an impact on the economic objectives. Accordingly, nearly all the benchmarks of the last two IMF programs pertained either to tax administration, customs, budgetary, or treasury reforms, or to the introduction of accounting, fiscal, or tax management instruments or IT applications. The measures envisaged under those programs thus made it possible to consolidate public finances and undertake structural reforms to enhance their effectiveness. But their real impact on economic growth and certain of its parameters, employment in particular, were not always discernible.

14. The 2003 assessment of the IMF program identified three major challenges: (i) consolidating the fiscal position; (ii) enhancing the business climate; and (iii) bolstering competitiveness and diversifying the economy. While it appears that real progress was made in terms of fiscal consolidation, much remains to be done with regard to the two other challenges.

15. Mali is experiencing relatively weak economic growth of about 5 percent, in contrast to a Strategic Poverty Reduction Framework target of 7 percent. The weakness of growth is linked to the low level of investment, as noted in the report. The low level of investment is in turn linked to the scarcity of financial resources. Poverty reduction will depend on the solution of these three problems. The challenge, then, is to mobilize more domestic and external resources to boost the level of productive investment and accelerate growth, especially growth that creates jobs and generates fiscal revenue, which are key to remaining in the virtuous circle of growth. 
16. The scope of the social challenges is such that most domestic financing goes to current expenditure in the fields of education and health. In support of domestic financing, Mali receives external financing from various partners. The volume of this financing clearly falls short of the country's actual financing requirements. Consequently, because of constraints linked to public debt conditionalities, the volume of debt and the amount of assistance received have prevented making enough key investments to achieve strong, sustainable economic growth.

17. The government hopes that the next update of the debt sustainability analysis with IMF and World Bank staff will include an opportunity to discuss and determine the size of the envelope of nonconcessional debt that would be compatible with debt sustainability, especially for the financing of economically viable projects.

18. The government is resolutely committed to increasing the financing of productive investment in order to jump start growth and combat poverty. To that end, the government hopes that this focus on economic recovery will be reflected in the next IMF program.

19. In conclusion, the government is determined to diversify the national economy and deepen the structural reforms, particularly those aimed at improving the business climate, increasing the mobilization of domestic resources, enhancing the effectiveness of public expenditure, and ensuring prudent public debt management. The government will place greater emphasis on the financing of productive investment in order to jump start economic growth and effectively combat poverty.

20. The government greatly appreciated the assessment exercise, especially the approach of sharing its conclusions in a spirit of openness with all components of Malian society, which also had an opportunity to express their viewpoints and concerns, some of which could contribute effectively to the discussion of a new program.

21. The government thanks the International Monetary Fund for the technical and financial assistance it receives. It reaffirms its commitment to pursuing reforms that are key to making Mali an emerging country. 


\section{Statement by Kossi Assimaidou, Executive Director for Mali}

\section{June 8, 2011}

1. My Malian authorities are thankful to the Board, Management, and the staff for the valuable policy advice they continue to receive from the Fund in support of the implementation of their economic program supported by the Extended Credit Facility (ECF). As the current ECF arrangement is headed toward its final months, they much appreciate the inclusive approach adopted by staff in the preparation of the Ex-Post Assessment (EPA) of the Fund's longer-term program engagement that is being considered by the Board along with the staff report.

2. Economic developments in 2010 were characterized notably by robust growth, low inflation, better-than-expected fiscal performance, weaker external position, and improved financial soundness indicators. In addition, program performance has been strong, with all end-December 2010 performance criteria and indicative targets being met, except for the indicative target on priority spending. On the structural front, all but one benchmark were implemented, thus translating into further improvements in tax and customs administration, lower vulnerabilities in the banking system, and better management of public finances. At the same time, the establishment of a system for managing and ensuring timely payment of value added tax credits to eligible companies - which is the essence of the missed benchmark - is underway.

\section{Policy and Reform Agenda for 2011}

3. The reform agenda will continue to place a heavy focus on measures aimed at increasing the efficiency of tax and customs administration, further improving debt management, strengthening public financial management and the financial system, and advancing reforms in the cotton sector.

4. On the fiscal front, prudence will continue to guide the authorities' policies, materializing into efforts aimed at containing the basic fiscal deficit. In this endeavor, necessary spending and revenue adjustments will be made in the context of the forthcoming supplementary budget. On the revenue front, additional resources are expected to be secured by improved tax collection and higher non-tax revenue. The implementation of the recently adopted pass-through mechanism of international oil prices to domestic prices will help protect revenue from taxation of petroleum products and thus limit the budgetary impact of higher global oil prices. Other key revenue-enhancing measures will include the three-year action plan to be developed with a view to streamlining tax legislation as well as the phasing out of the preferential import tax regime benefiting some gold mining companies and the value-added tax exemptions granted to their subcontractors. On the expenditure front, better management of non-priority capital spending is expected to play a key role going forward. 
5. Implementation of the government public financial management action plan will be pursued. In particular, steps will be taken to ensure increased compliance of budget preparation, execution and transparency with regional standards. In this connection, specific measures that are envisaged include analyzing the implications of transferring accounts held by government entities in commercial banks to the Treasury account at the central bank and improving the presentation of fiscal tables.

6. In order to strengthen debt management, the authorities plan to put in place a comprehensive database of domestic debt contracts and government guarantees. While preference will continue to be given to concessional financing, the authorities will determine with staff in the context of the next DSA exercise the level of nonconcessional borrowing that could be consistent with the need to preserve debt sustainability.

7. Financial sector reform will continue to be guided by the authorities' financial sector development strategy. In particular, work will continue to be undertaken toward completing the restructuring of the state housing bank (BHM) and increasing capital requirements of banks and other financial institutions. Strengthening the supervision of microfinance institutions will also remain central in the financial sector reform agenda; so will be improving credit access to small and medium-sized enterprises.

8. Cotton sector reform will be pursued with the ultimate aim of completing the ongoing process of privatizing the cotton ginning company, CMDT, while safeguarding the viability of the cotton sector. Recent progress made toward this goal relates to the recent selection of an investor interested in buying two of the four CMDT subsidiaries. Efforts will be made to find other potential buyers of remaining subsidiaries.

9. It is the authorities' view that an augmentation of access under the Extended Credit Facility (ECF) would contribute to mitigating the impact of the recent and ongoing crises in Cote d'Ivoire and Libya on the balance of payments. The main transmission channels of these crises include lower remittances, weaker foreign direct investment, and increased vulnerabilities in the banking system. In view of Mali's exposure to these external shocks, Directors' support for the requested augmentation of access under the ECF would be welcome.

\section{Ex-Post Assessment of Longer-Term Program Engagement}

10. At this juncture, the Ex-Post Assessment (EPA) of the Fund's longer-term program engagement in Mali is timely and welcome. Encouragingly, the EPA notes that some of the key achievements under the last Fund-supported programs under review relate to the maintenance of macroeconomic and financial stability and sustainable external debt position. However, the EPA conclusion that the last two Fund-supported programs were only partially effective in achieving core objectives calls for further improvements in program design. 
11. While the recent streamlining of conditionality is a step in the right direction, there seems to be scope for program design to do a better job of helping achieve growth and poverty reduction objectives' set forth in Mali's Fund-supported programs. Indeed, as noted in the EPA report, although both Fund-supported programs under review placed a heavy focus on growth in line with the recommendations made in the $2003 \mathrm{EPA}$, growth was still weaker than average growth in Sub-Saharan Africa.

12. While the EPA rightly stresses the need for the Malian authorities to diversify the economy and promote private sector development to raise the country's growth potential, it would have been useful if it had underscored how program design could better contribute to this desirable goal. For instance, program conditionality on public debt and insufficient external financing constitute, in the authorities' view, key impediments to the achievement of adequate levels of public investment needed for strong and sustainable economic growth. Unfortunately, the EPA disregards how program requirements in the area of debt management may have constrained program growth objectives. Moreover, while the heavy focus of program conditionality on fiscal reform may have been useful in maintaining moderate levels of fiscal deficits, it is not clear that it contributed to creating fiscal space for development spending. Indeed, as the authorities noted in their response to the EPA, implementation of structural conditions on the fiscal front may have led to fiscal consolidation but their effects on economic growth have not been always perceptible.

13. In the concluding section of the EPA report, staff notes that the lack of ownership by key domestic stakeholders was the primary cause of the slow implementation of structural reforms. Unfortunately, it does not explicitly identify other factors related to program design that could have played a role in explaining the uneven program performance on the structural front. For instance, the EPA conclusion that implementation of structural reforms improved in recent years following greater ownership and the streamlining of the reform agenda seems to suggest that aspects of program design might have contributed to this outcome but the report does not further elaborate on this issue. In addition, the EPA questions whether program measures related to the privatization of CMDT are likely to solve the problems facing the cotton sector and whether the privatization of the BHM could be completed without taking steps to improve the soundness of the bank.

14. Based on the good program performance and the policy objectives under the ECF, I would appreciate Directors' favorable consideration of my authorities' request for the completion of the sixth review and modification of the performance criteria for the seventh review under the ECF. 
Public Information Notice (PIN) No. 11/78 FOR IMMEDIATE RELEASE June 17, 2011
International Monetary Fund

$70019^{\text {th }}$ Street, NW

Washington, D. C. 20431 USA

\section{IMF Executive Board Discusses the Ex Post Assessment of Longer-Term Program Engagement with Mali}

On June 13, 2011, the Executive Board of the International Monetary Fund (IMF) discussed the Ex Post Assessment (EPA) of Longer-Term Program Engagement with Mali.

\section{Background}

An EPA is required for all members having longer-term program engagement with the Fund. EPAs are intended to provide an opportunity to step back from continuing program relations to consider an analysis of the economic problems facing the country, review progress under Fund-supported programs, and draw forward-looking lessons for future Fund engagement.

Since the late 1980s, Mali has almost continuously had a program supported by the Fund under its various concessional lending facilities. In December 2003, a first ex post assessment concluded that Mali had made important progress with respect to macroeconomic management and implementation of structural reforms, but that key challenges remained, including consolidating the fiscal position, bolstering competitiveness and diversifying the economy, and enhancing the business climateincluding through privatization and improved governance-in order to spur growth and reduce poverty.

This EPA reviewed Fund's involvement in Mali from 2004 to 2011, focusing on the implementation of the 2004-07 program supported by the then-existing Poverty Reduction and Growth Facility (PRGF), and the 2008-11 program supported by the PRGF/Extended Credit Facility (ECF) arrangement.

\section{Executive Board Assessment}

Directors noted the findings of EPA of Longer-Term Program Engagement. While the program objective of macroeconomic and financial stability was broadly achieved, as evidenced by the moderate fiscal deficits, low and relatively stable rates of inflation, and 
the maintenance of a sustainable external debt position, raising economic growth remained a challenge. As highlighted by the EPA, Directors agreed that decisive implementation of structural reforms would be necessary to create conditions for encouraging higher private sector investment and employment. They also agreed that the findings of the EPA would provide helpful guidance in the design of future Fund engagement.

Directors noted that a successor Fund-supported program would help Mali meet its large external financing requirements and strengthen its efforts on structural reforms.

Public Information Notices (PINs) form part of the IMF's efforts to promote transparency of the IMF's views and analysis of economic developments and policies. With the consent of the country (or countries) concerned, PINs are issued after Executive Board discussions of Article IV consultations with member countries, of its surveillance of developments at the regional level, of post-program monitoring, and of ex post assessments of member countries with longer-term program engagements. PINs are also issued after Executive Board discussions of general policy matters, unless otherwise decided by the Executive Board in a particular case. 